\title{
Eggshell and Histology Provide Insight on the Life History of a Pterosaur with Two Functional Ovaries
}

\author{
XIAOLIN WANG ${ }^{1}$, ALEXANDER W. A. KELLNER ${ }^{2}$, XIN CHENG ${ }^{1,2}$, \\ SHUNXING JIANG ${ }^{1}$, QIANG WANG ${ }^{1}$, JULIANA M. SAYÃ ${ }^{3}{ }^{3}$, TAISSA RODRIGUES ${ }^{4}$, \\ FABIANA R. COSTA $^{5}$, NING LI ${ }^{1,6}$, XI MENG $^{1}$ and ZHONGHE ZHOU ${ }^{1}$
}

\author{
${ }^{1}$ Key Laboratory of Vertebrate Evolution and Human Origins of Chinese Academy of Sciences, Institute of Vertebrate \\ Paleontology and Paleoanthropology, Chinese Academy of Sciences, P. O. Box 643, Beijing 100044, China \\ ${ }^{2}$ Laboratory of Systematics and Taphonomy of Fossil Vertebrates, Department of Geology and Paleontology, Museu Nacional / \\ Universidade Federal do Rio de Janeiro, Quinta da Boa Vista, s/n, São Cristóvão, 20940-040 Rio de Janeiro, RJ, Brasil \\ ${ }^{3}$ Centro Acadêmico de Vitória, Universidade Federal de Pernambuco, Rua do Alto Reservatório, s/n, \\ Bela Vista, 55608-680 Vitória do Santo Antão, PE, Brasil \\ ${ }^{4}$ Departamento de Biologia, Centro de Ciências Agrárias, Universidade Federal do Espírito Santo. \\ Alto Universitário, s/n, Caixa Postal 16, Guararema, 29500-000, Alegre, ES, Brazil \\ ${ }^{5}$ Department of Biological Sciences, Environmental Sciences Sector, Universidade Federal de São Paulo, \\ Prof. Artur Riedel, 275, Jardim Eldorado, 09972-270 Diadema, SP, Brasil \\ ${ }^{6}$ University of Chinese Academy of Sciences, Beijing 100049, China
}

Manuscript received on May 20, 2015; accepted for publication on June 12, 2015

\begin{abstract}
The counterpart of a previously described non-pterodactyloid pterosaur with an egg revealed the presence of a second egg inside the body cavity of this gravid female. It clearly shows that pterosaurs had two functional oviducts and demonstrates that the reduction of one oviduct was not a prerequisite for developing powered flight, at least in this group. Compositional analysis of one egg suggests the lack of a hard external layer of calcium carbonate. Histological sections of one femur lack medullary bone and further demonstrate that this pterosaur reached reproductive maturity before skeletal maturity. This study shows that pterosaurs laid eggs even smaller than previously thought and had a reproductive strategy more similar to basal reptiles than to birds. Whether pterosaurs were highly precocial or needed parental care is still open to debate.
\end{abstract}

Key words: Pterosauria, Wukongopteridae, Reproductive Biology, Jurassic, China.

\section{INTRODUCTION}

Information about the reproductive biology of extinct animals is hard to be retrieved from the fossil record, particularly if suitable modern analogs are not available. This is particularly true for pterosaurs, a distinct group of oviparous reptiles that were the first vertebrates to develop powered flight (e.g., Kellner

Correspondence to: Xiaolin Wang

E-mail: wangxiaolin@ivpp.ac.cn

Alexander W.A. Kellner

E-mail:kellner@mn.ufrj.br
2006). As known for extant and extinct vertebrates, some information about the reproductive strategy can be gathered by studying the structure of the eggshell (e.g., Deeming 2004, Grellet-Tinner et al. 2007). Pterosaur eggs are exceptionally rare and only a few specimens have been reported. The first two came from the Early Cretaceous (Barremian-Aptian) Yixian Formation in China (Wang and Zhou 2004, Ji et al. 2004) and the third from the Early Cretaceous (Aptian) Lagarcito Formation in Argentina (Chiappe 
et al. 2004). All eggs were found isolated and show embryos in different degrees of preservation that were regarded to represent pterodactyloid taxa, but only the latter could be identified at the species level (Chiappe et al. 2004). More recently, Wang et al. (2014) reported five exceptionally well-preserved eggs associated with hundreds of pterosaur bones from Hami, located in the Xinjiang Uyghur Autonomous Region of China, and a tridimensionally preserved egg was retrieved from the Lagarcito Formation and referred to Pterodaustro guinazui (Grellet-Tinner et al. 2014).

Another important discovery of a pterosaur egg was described by Lü et al. (2011a) from the Late Jurassic Tiaojishan Formation in China. The fossil, housed in the Zhejiang Museum of Natural History (Hangzhou, Zhejiang Province, China; ZMNH M8802) consists of a skeleton showing an egg situated posterior to the pelvis, which has been interpreted as parchment-shelled. This specimen is reported to have been discovered by a local farmer at Linglongta in the Liaoning Province.
The egg consists of the external impression only, and no tests were performed to assess the presence of a calcareous external layer. This became more interesting due to the fact that the Argentinean material shows a thin external layer composed of calcium (Chiappe et al. 2004, Grellet-Tinner et al. 2007, 2014) which was also reported in the tridimensionally preserved eggs from China (Wang et al. 2014).

Recently the counter slab of ZMNH M8802 was recovered and is now permanently deposited in the collections of the Institute of Vertebrate Paleontology and Paleoanthropology of the Chinese Academy of Sciences in Beijing (IVPP V18403; Fig. 1). The specimen shows the first egg much better preserved and further reveals a second one inside the body cavity of this female individual (Fig. 2). Scanning Electron Microscope (SEM) analyses and paleohistological sections of this specimen have revealed novel important information that sheds new light on the life history of this gravid pterosaur,
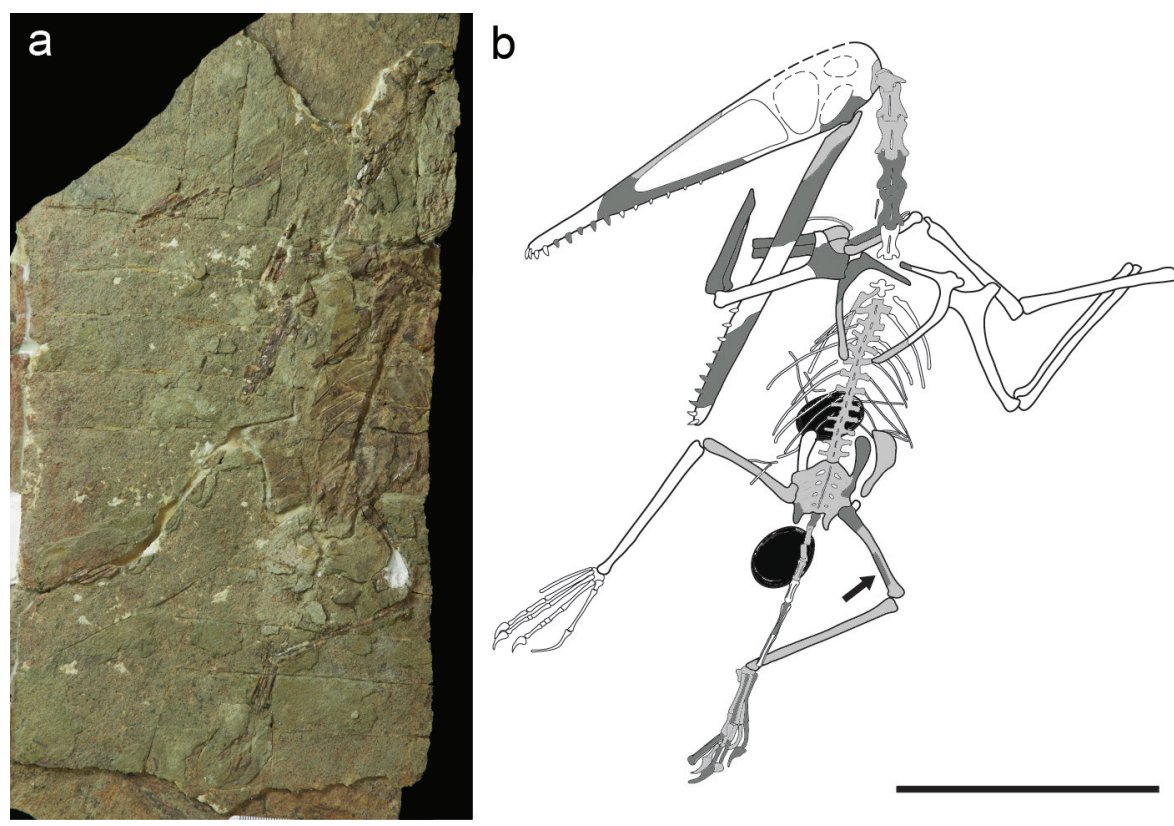

Fig. 1 - Gravid pterosaur of Kunpengopterus sp. with two eggs, one inside the body cavity and a second posterior to the pelvic region. (a) Counter slab (IVPP V18403). (b) Composite drawing of slab and counter slab indicating the position of the eggs and the bones (in grey) preserved in the counter slab. The arrow indicates the part of the femur removed for histological sections. Scale bar, $100 \mathrm{~mm}$. 

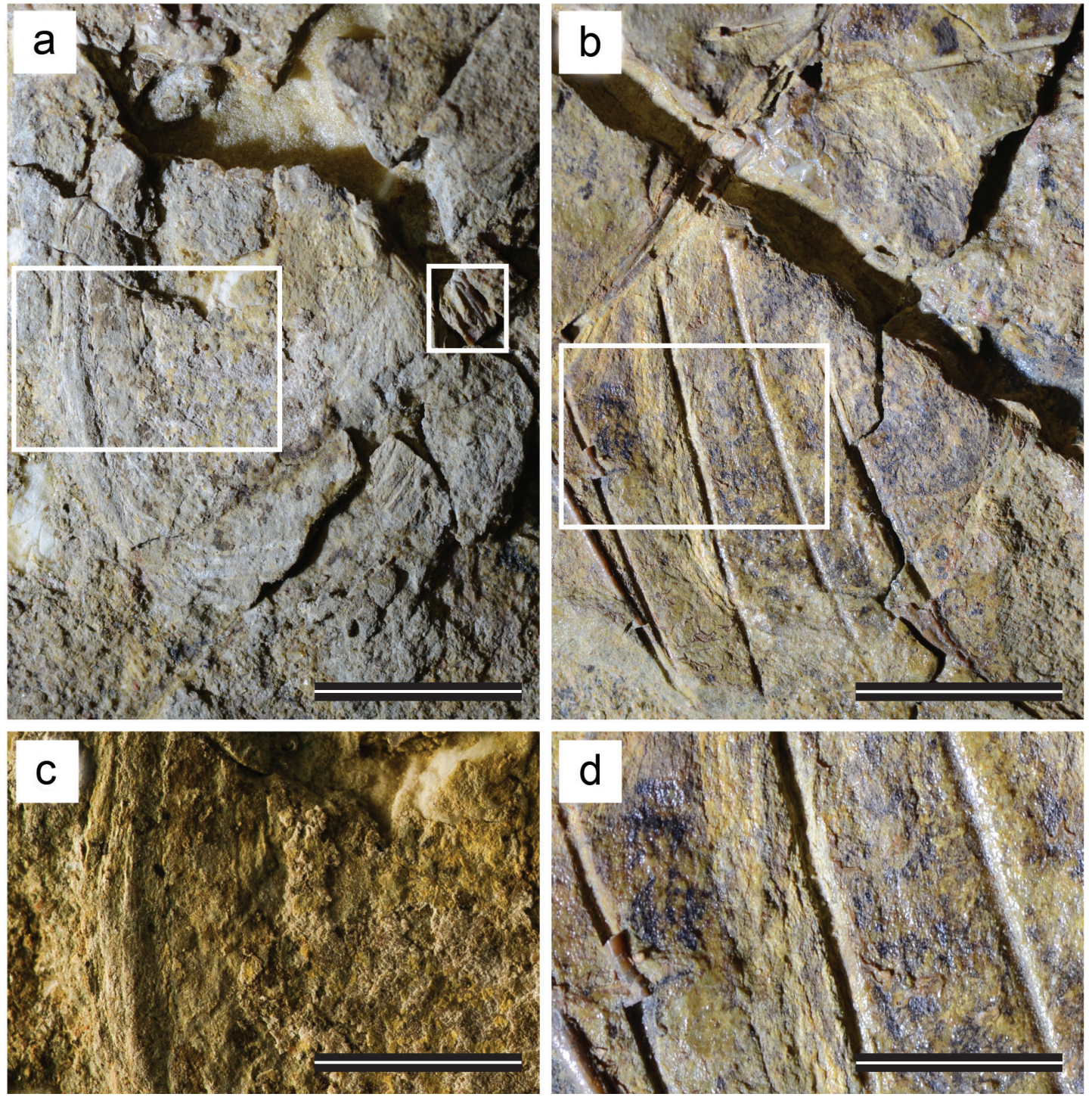

Fig. 2 - Close up of the eggs - (a) posterior to the pelvis, the right frame indicating the area of the eggshell sample taken for EDS. (b) inside the body cavity. (c) Close up in the left frame of (a), showing the detail of the egg surface located posterior do the pelvis. (d) Close up in the frame of (b), showing the detail of the egg surface located inside the body cavity. Scale bar, (a) and (b) $10 \mathrm{~mm}$, (c) and (d) $5 \mathrm{~mm}$.

including the reproductive strategy that might apply for a wide range of these flying reptiles.

\section{DESCRIPTION}

The specimen ZMNH M8802/IVPP V18403 was originally referred to the wukongopterid Darwinopterus (Lü et al. 2011a) without proper justification since this non-pterodactyloid group has proven to be rather diverse (Wang et al. 2009, 2010,
Lü et al. 2011b). The skull of this pterosaur is partially preserved in the counter slab as an impression and confirms that this specimen lacks a premaxillary crest (Lü et al. 2011a). Although incomplete, the posterior part of the skull appears to be rounded, differing from Darwinopterus and being similar to Kunpengopterus sinensis (Wang et al. 2010). Based on the measurements and figures from Wang et al. (2009, 2010) and Lü et al. (2010, 2011a, b), IVPP V18403 
has the shortest nasoantorbital fenestra relative to the skull length (naof/s) in all wukongopterids (naof/s $=0.41$ ), except for Kunpengopterus (naof/s =0.35). The teeth are comparatively small, cone-shaped, with striated enamel, similar to Kunpengopterus but different from Darwinopterus linglongtaensis (Wang et al. 2010). They are also shorter than those of Darwinopterus modularis (Lü et al. 2010). The ilium has the preacetabular portion plate-like and elongated, differing from the short condition observed in Wukongopterus (Wang et al. 2009). The second phalanx of the fifth pedal digit is boomerangshaped and differs from all other wukongopterids by having the proximal and distal parts sub equal in size, while the angle $\left(137^{\circ}\right.$; Fig. 3$)$ between these parts is similar to that of Kunpengopterus sinensis (Wang et al. 2010). The first phalanx of this toe is peculiar in being longer than the metatarsal IV, a unique feature among wukongopterids (Fig. 3). Based on the available anatomical information, this specimen is tentatively regarded as Kunpengopterus sp.

Two eggs can be clearly identified in this specimen. The first was previously reported in the main slab (Lü et al. 2011a) where it is preserved as an impression, while the most complete part remained on the counter slab (IVPPV18403). This egg is positioned on the left side of the specimen, immediately posterior to the pelvis, partially overlapping the tail, and can be distinguished from the brownish sedimentary matrix by its whitish-grey coloration. It is flattened and the edges show concentric folds that stand out at a slightly higher level than the remaining portion of the egg. The longest axis has $27.8 \mathrm{~mm}$ and the shortest $19.8 \mathrm{~mm}$. The center shows a rather uneven surface, and folding towards the margin of the egg is more extensive than in the center. The surface in some areas present papilla-like structures, but no crazing or cracking is apparent.
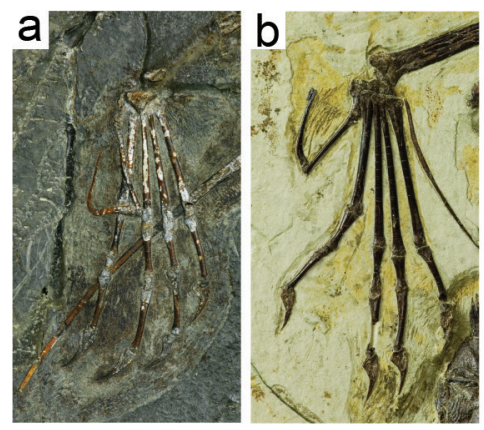

f

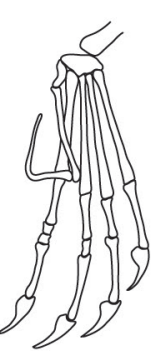

g

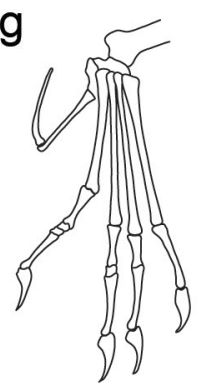

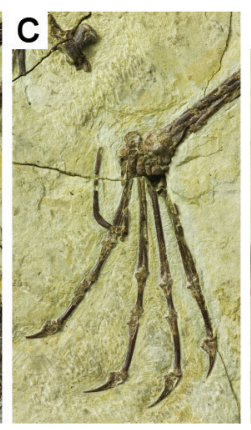

$\mathrm{h}$

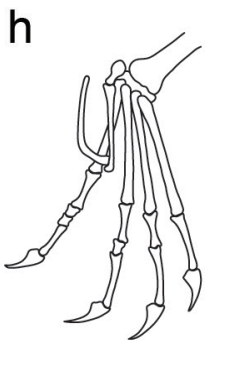

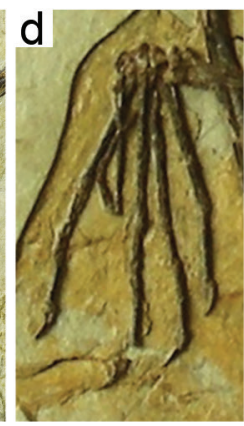

i

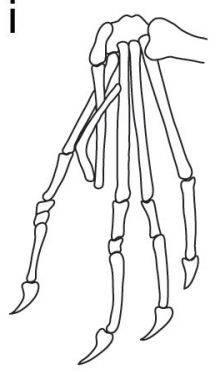

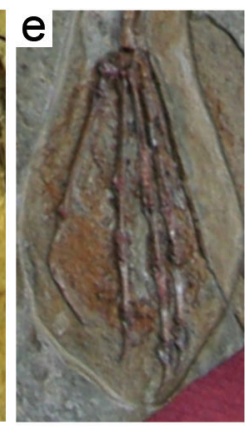

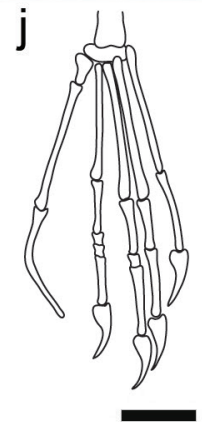

Fig. 3 - Photos and drawings showing the variation in the morphology of the feet within the pterosaur clade Wukongopteridae. (a) and (f) Wukongopterus (inverted; based on Wang et al. 2009), (b) and (g) Kunpengopterus sinensis (based on Wang et al. 2010), (c) and (h) Darwinopterus linglongtaensis (based on Wang et al. 2010), (d) and (i) Darwinopterus robustodens (based on Lü et al. 2011b), (e) and (j) Kunpengopterus sp. (based on Lü et al. 2011a). Scale bar, $10 \mathrm{~mm}$. Darwinopterus modularis is not included since the holotype lacks a complete foot (Lü et al. 2010). 
The second egg is positioned on the left side of the body, immediately anterior to the pelvis. It is associated with several ribs and elements of the gastralia, and was clearly preserved inside the body cavity of the animal. Being $27.9 \mathrm{~mm}$ long and $18.2 \mathrm{~mm}$ wide, it shows a slightly more elongated outline than the first. The margins are formed by concentric folds that show a yellowish color. The inner region also shows ridges indicating that folding was present, but overall it seems to be less preserved than the first egg.

Both eggs are flattened, have almost the same length, and differ from each other in their width. In order to estimate the variation in dimension introduced by compression, we took a hatched pliable snake egg (Elaphe taeniura), left it in water until it became waterlogged and compressed it to approach the condition of the pterosaur eggs (Table I, II). This exercise revealed that while the variation in length is small (2.31-4.67\%), in width it is quite large (12.37$18.77 \%$ ). Consequently, some compensation for the compression should be taken into account in any mass estimative of egg and hatchling in compressed specimens. When applied to the pterosaur material (IVPP V18403), the dimensions of the first and second eggs corrected for compression could vary from 27.2 x $17.4 \mathrm{~mm}$ to 26.6 x $14.8 \mathrm{~mm}$. Considering both eggs, this leads to an estimate of an initial egg mass (IEM; Hoyt 1979) between $3.19 \mathrm{~g}$ and $4.50 \mathrm{~g}$, which are about $27 \%$ to $48 \%$ lower than previously thought (Lü et al. 2011a). The hatchling mass (HM) considering both eggs vary from $2.75 \mathrm{~g}$ to $3.75 \mathrm{~g}$, and was about $24 \%$ to $44 \%$ lower than previously calculated (Deeming and Birchard 2007, Lü et al. 2011a).

TABLE I

Variation in dimensions of a dried, waterlogged and compressed hatched snake egg of Elaphe taeniura (Megalopdiidae). It was left in water for $\mathbf{2 4}$ hours and then compressed. This process was repeated a second time, with the same egg left for 72 hours in water. This experiment shows that the length and width increase due to compression and varied between $2.31 \%$ to $4.67 \%$ and $12.37 \%$ to $18.77 \%$ respectively.

\begin{tabular}{|c|c|c|}
\hline & Dimensions (mm) & Dimensions (mm) \\
\hline Hatched egg - dried & $42.7 \times 25.4$ & $42.7 \times 25.4$ \\
\hline Hatched egg - waterlogged & $46.6 \times 26.2(24 \mathrm{hs})$ & $47.0 \times 26.4(72 \mathrm{hs})$ \\
\hline Hatched egg - waterlogged - compressed & $47.7 \times 29.9(24 \mathrm{hs})$ & $49.3 \times 32.5(72 \mathrm{hs})$ \\
\hline
\end{tabular}

TABLE II

Estimation of the egg and hatchling masses.

\begin{tabular}{|c|c|c|c|c|}
\hline & $\begin{array}{c}\text { Egg dimensions } \\
(\mathbf{m m})\end{array}$ & $\begin{array}{c}\text { Estimated dimensions } \\
\text { corrected for compaction }\end{array}$ & $\begin{array}{c}\text { Initial egg mass } \\
(\mathbf{g}) \text { (IEM) }\end{array}$ & $\begin{array}{c}\text { Hatchling mass } \\
(\mathbf{g})(\mathbf{H M})\end{array}$ \\
\hline Lü et al. 2011a (S1) & $28 \times 20$ & - & 6.13 & 4.95 \\
Egg 1 & - & $27.2 \times 17.4^{*}$ & 4.50 & 3.75 \\
\hline \multirow{2}{*}{ Egg 1 } & $27.8 \times 19.8$ & $26.5 \times 16.1^{* *}$ & 3.76 & 3.19 \\
\hline \multirow{2}{*}{ Egg 2 } & $27.9 \times 18.2$ & $27.3 \times 15.9^{*}$ & 3.78 & 3.20 \\
\hline
\end{tabular}

* Corrected based on the values of the $24 \mathrm{hs}$. waterlogged snake egg; ** corrected based on the 72 hs waterlogged snake egg; IEM $=0.547 \mathrm{LB}^{2}$, where $\mathrm{L}=$ length and $\mathrm{B}=$ breadth $^{7,10} ; \mathrm{HM}=\left(0.964 \mathrm{IEM}^{0.903}\right)^{7,11}$.

\section{DISCUSSION}

In order to test if the eggs of IVPP V18403 had calcium carbonate in the external layer, a fragment of the eggshell was submitted to Energy Dispersive
Spectroscopy (EDS) done under SEM (Fig. 4). This analysis neither revealed substantial traces of calcium carbonate nor showed any significant composition difference between the matrix and the 
eggshell. This indicates that the calcium carbonate from the eggshell was either removed during the fossilization process, was resorbed during embryogenesis (Grellet-Tinner et al. 2014), or that none was present at all. Another alternative is that these eggs were not in the calcifying developmental stage when the animal died. This last hypothesis is supported by the comparatively small size of these eggs, with one still inside the body while the other most likely was expelled during the fossilization process (Lü et al. 2011a) and was not actually laid.

In an attempt to solve this issue, a small part of the shaft corresponding to the metaphysis close to the distal articulation of the right femur of IVPP
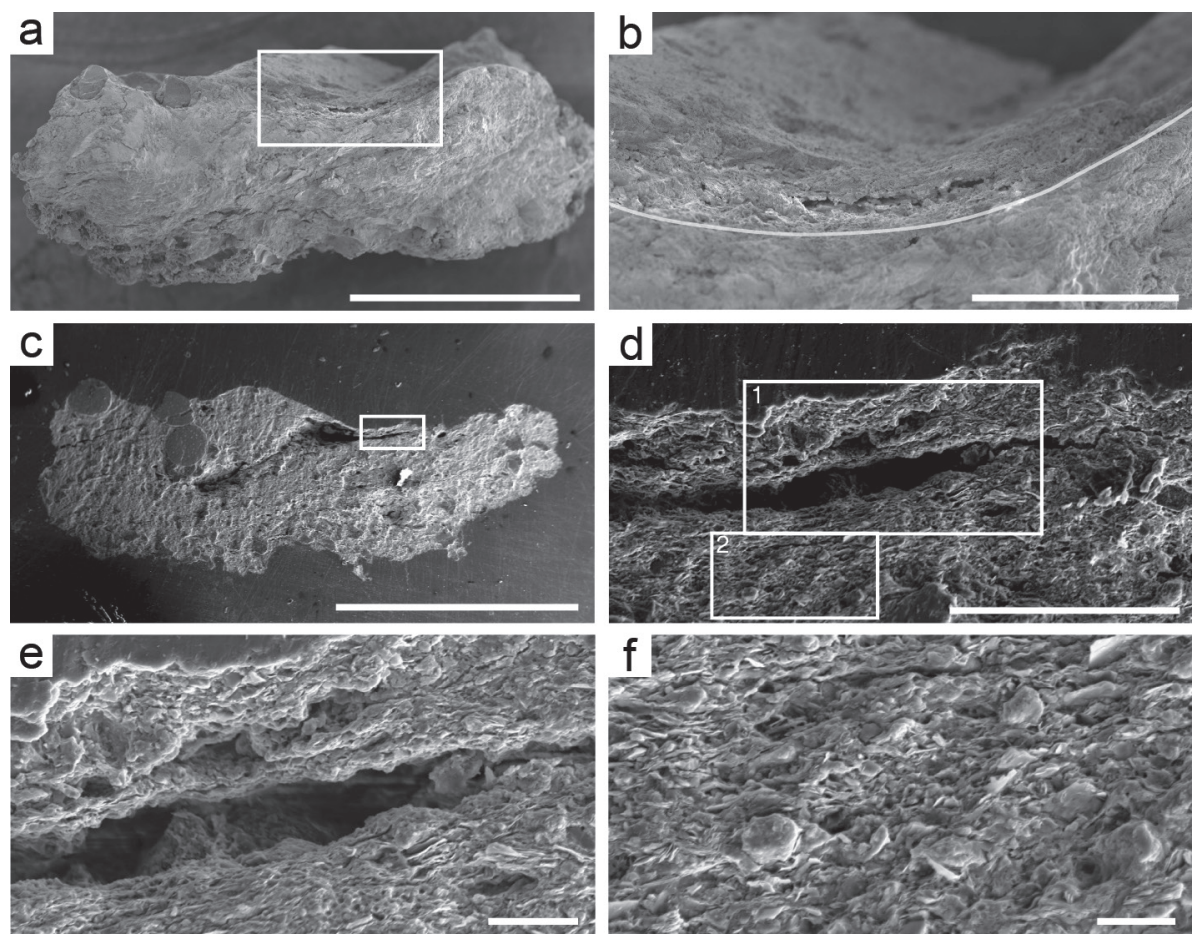

Fig. 4 - Sample (covered with a gold layer) showing the microstructure of the eggshell and matrix of IVPP V18403 under Scanning Electron Microscope (SEM). (a) Complete sample before being embedded in resin. (b) Close-up in the frame of (a), showing the eggshell. The line indicates the boundary between the eggshell and the inner matrix. (c) Resin-embedded specimen after polishing. (d) Close-up in the frame of (c); (e) and (f) close-up in the frames (1) and (2) of (d), respectively, showing the fibrous membrane of the eggshell. No external hard calcareous layer was found. Scale bars, (a) and (c) $1 \mathrm{~mm}$; (b) $300 \mu \mathrm{m}$; (d) $100 \mu \mathrm{m}$; (e) $20 \mu \mathrm{m}$; (f) $10 \mu \mathrm{m}$.

V18403 was removed for paleohistological sections (Fig. 1, 5). It is known that gravid oviparous females develop a bone tissue called medullary layer during the ovulation period and the egg-laying phase, which was observed in extant birds and non-avian dinosaurs (Reiss 1989, Schweitzer et al. 2005, Lee and Werning 2008). This bone tissue is a fast way for females to remobilize calcium to form the rigid external eggshell (Pahl et al. 1997).
Like in other pterosaurs, the femur is pneumatic, with the cortical bone about $0.4 \mathrm{~mm}$ thick. Due to crushing, the bone is collapsed and the original dimension of the marrow cavity, which is large and completely filled with minerals, cannot be restored. There was neither any evidence of cancellous bone or bony struts forming trabeculae, wich have been reported in some other bones of derived pterosaurs (e.g., Kellner 2006), nor of medullary bone. This 
finding is consistent with the eggs of this pterosaur being parchment-shelled.

Still regarding the medullary layer, although the phylogenetic position of pterosaurs within the Diapsida is disputed (e.g., Bennett 2013), most authors agree that they are more closely related to dinosaurs than to crocodylomorphs (e.g., Kellner 2004, Hone and Benton 2008). Consequently, the absence of medullary layer in this gravid pterosaur concurs with the hypothesis that the development of this tissue was an evolutionary novelty in the dinosaur-bird lineage (Schweitzer et al. 2007).
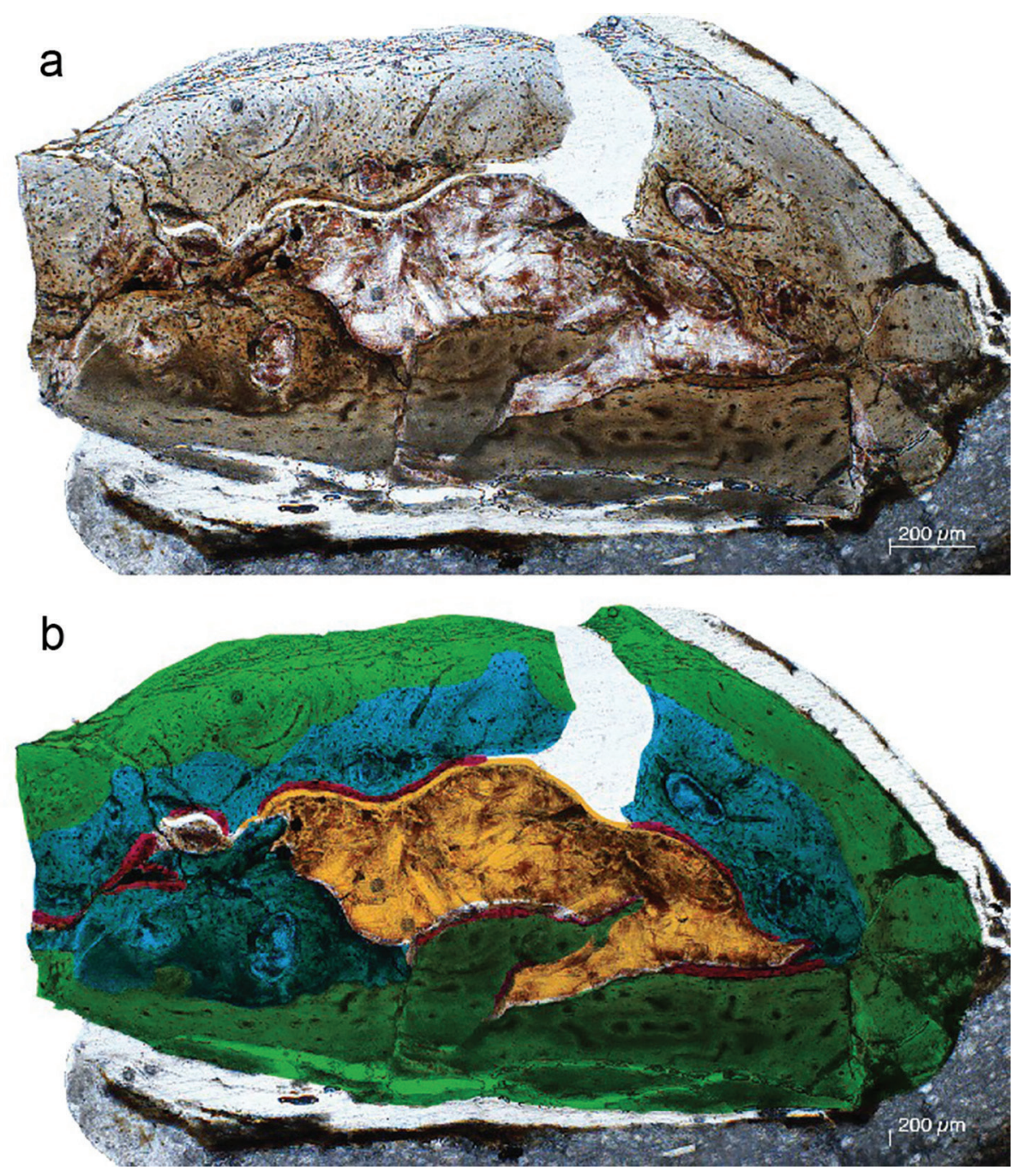

Fig. 5 - Histological section of the transverse section of the femur (IVPP V18403) close to the distal articulation of Kunpengopterus sp. (a) Thin section showing the general histological pattern. (b) Colors indicate the three distinct layers of bone tissue. From outside to inside: outer cortex (green); perimedullar compacted bone tissue with erosion cavities (blue); inner circumferential lamellar bone (red) and the marrow cavity filled by minerals (orange). Scale bar, $200 \mu \mathrm{m}$.

The histological section has also revealed other important features. Overall, the femur is well vascularized and three distinct layers of bone tissue were observed (Fig. 5). The outer cortex is composed of bone tissue containing several osteocyte lacunae and a reduced number of vascular 
channels. The orientation of these channels was predominantly longitudinal with similar diameters $(=12 \mu \mathrm{m})$. One faint line was observed but lacks continuity as would be expected for a line of arrested growth (LAGs, Sayão 2003, Chinsamy et al. 2009, Prondvai et al. 2012). No evidence of avascular periosteal lamellae (external fundamental system - EFS) was found.

The second layer is unusual since it shows uncommon perimedullar compacted bone tissue with erosion cavities under the primary osteons. It is less vascularized and shows six resorption zones varying from $41.7 \mu \mathrm{m}$ to $99.21 \mu \mathrm{m}$. During growth, this area was submitted to a sequence of bone deposition, resorption and transformation from cancellous spongiosa to compacted spongiosa (Steel 2008), which does not occur in the mid-shaft. A reversal line could be observed. No plywood bone was found, which is regarded as unique to pterosaurs (Ricqlès et al. 2000) and was reported in some derived species (e.g., Sayão 2003, Steel 2008). Its absence in IVPP V18403 corroborates the notion that plywood bone tissue is unevenly distributed among these flying reptiles (Steel 2008, Chinsamy et al. 2009).

The deepest layer lining the medullar cavity is formed by a thin layer of inner circumferential lamellar bone (= avascular endosteal lamella), with several osteocyte lacunae. This structure is thought to be deposited after endosteal resorption has ceased or slowed (Steel 2008, Chinsamy et al. 2009), but it was recently observed in juveniles of the non-pterodactyloid Rhamphorhynchus (Prondvai et al. 2012).

The skeleton preserved in the main slab (ZMNH M8802) was reported to show several ossified elements and thus regarded to represent an adult that had completed the main growth phase (Lü et al. 2011a). However, the reported coossification and fusion pattern is at odds with the histological section. IVPP V18403 is clearly not a juvenile nor an osteologically mature specimen since it lacks EFS. The latter has bone tissue that indicates that the animal has reached asymptotic body size, with growth having essentially ceased (Steel 2008, Kellner et al. 2013), and its absence here argues that this pterosaur was still growing at the time of death.

There are also no lines of arrested growth (LAGs), which were observed in several histological sections of extant and extinct tetrapods and have been used to establish the age of the animal (Castanet and Smirina 1990). In these volant reptiles endosteal resorption is regarded as very extensive (Prondvai et al. 2012) and only the most recent chapter of a pterosaur's life might be captured by the bones. Therefore, it is possible that any bone tissue showing LAGs might have been resorbed. Based on the LAGs, it has been interpreted that the pterodactyloid Pterodaustro reached reproductive maturity in two years and skeletal maturity in four (Chinsamy et al. 2009). However, the periodicity in the deposition of LAGs in pterosaur bones should be used with caution since it has been demonstrated to be inconstant in the skeleton of a same individual (Sayão 2003). In any case, the absence of LAGs, annulus and cyclic patterns of growth in the histological section of IVPP V18403 does not allow the establishment of when this pterosaur reached reproductive maturity. The present evidences show that this specimen most likely represents a late juvenile or a subadult female in the reproductive phase, and the reported fusion of bones that led to the conclusion of osteological maturity (Lü et al. 2011a) might have been misinterpreted. It should be noted that in osteologically mature pterosaurs the pelvic elements tend to fuse, different from what is observed in this pterosaur, which indicates that reproductive maturity was reached before skeletal maturity.

Despite the different mass estimation of both eggs, with the one inside the body cavity being about $15.4 \%$ lighter than the other, all observable features suggest that they were at a similar 
developmental stage. This corroborates the idea that this pterosaur had two productive oviducts, which is the most common condition within extant reptiles (Norris and Lopez 2010, Zheng et al. 2013). The presence of two eggs in the pelvic region reported in an oviraptorosaurian and in a specimen of Sinosauropteryx (Sato et al. 2005) also leads to the interpretation that these species bear two functional oviducts, a feature regarded as widespread among non-avian dinosaurs, and that can now be demonstrated in pterosaurs as well.

Some reptiles, however, have the left oviduct reduced or completely lost (Norris and Lopez 2010). This asymmetry of the reproductive system is a derived condition that reduces the body mass and is particularly observed in birds that might have developed this condition as an adaptation for flight or production of fewer and larger eggs (Witschi 1935). The study of IVPP V18403 demonstrates that pterosaurs have retained the primitive condition. It further indicates that the reduction of one functional oviduct is clearly not a precondition for developing active flight since pterosaurs were the first vertebrates to develop this mode of aerial locomotion. Furthermore, the eggs of this gravid female were small and probably did not constitute a significant impediment for this animal to fly.

\section{CONCLUSION}

IVPP V18403 brings the first evidence that pterosaur laid eggs in pairs. The lack of additional eggs indicates that each oviduct produced one sole egg, simultaneously. Due to the width limits of the pelvic channel, even considering the pliable nature and the potential for the pelvis to spread out, eggs must have been laid sequentially. Since the time necessary for the egg formation in the pterosaur body is unknown, and due to the lack of a nest that could be attributed to this group of flying reptiles, clutch size cannot be established. There is a great degree in the variation of the reproductive strategy in reptiles, but animals with small parchment-like eggs tend to have clutch sizes with a comparatively high number of eggs and precocial hatchlings (Tinkle et al. 1970, Deeming 2004), which was regarded as the condition for pterosaurs (Lü et al. 2011a). Histological studies on the non-pterodactyloid Rhamphorhynchus, however, have pointed out that hatchlings were flightless until developing some somatic maturity (Prondvai et al. 2012, contra Lü et al. 2011a). More work and specimens are necessary to confirm either hypotheses. In any case, this remarkable fossil (ZMNH M8802/IVPP $\mathrm{V} 18403$ ) shows that pterosaurs had two functional oviducts and, together with the information from the other known pterosaur eggshells (Grellet-Tinner et al. 2014, Wang et al. 2014), demonstrates that pterosaurs developed several distinct reproductive strategies, including parchment-like and pliable eggshells. These findings bring further evidence of this group of volant archosaurs having a more typical reptilian than avian reproduction pattern.

\section{ACKNOWLEDGMENTS}

We thank L Xiang for the preparation of the specimens, W Gao for the photos, W-D Zhang and Z-X Zhang for their help in SEM and EDS, and R. Bantim for helping preparing the thin section. This study was supported by the Hundred Talents Project of Chinese Academy of Sciences, the National Key Basic Research Program of China (2012CB821900) and the National Science Fund for Distinguished Young Scholars (40825005). Additional funding was provided by the Conselho Nacional de Desenvolvimento Científico e Tecnológico (CNPq \#304780/2013-8 to AWAK, \#458164/2014-3 and \#310799/2014-7 to JMS, and \# 460784/2014-5 to TR); by the Fundação Carlos Chagas Filho de Amparo à Pesquisa do Rio de Janeiro (FAPERJ \# E-26/102.737/2012 to AWAK) and the Fundação de Amparo à Pesquisa e Inovação do Espírito Santo (FAPES/CNPq \# 52986870/2011 to TR). We also thank two reviewers for the comments that improved the final version of the manuscript. 


\section{RESUMO}

A contraparte de um espécime anteriormente descrito, contendo uma fêmea de pterossauro não-pterodactiloide com um ovo, revela a existência de um segundo ovo, este situado dentro da cavidade corporal desta fêmea prenhe. O exemplar demonstra claramente que os pterossauros possuíam dois ovidutos funcionais, e evidencia que a redução de um oviduto não foi um pré-requisito para o desenvolvimento do voo ativo pelo menos neste grupo. A análise da composição de um dos ovos sugere a ausência de uma camada externa formada por carbonato de cálcio. Seções histológicas de um fêmur não registram osso medular e demonstram que este pterossauro atingiu maturidade reprodutiva antes da maturidade óssea. O presente estudo evidencia que os pterossauros punham ovos de tamanho ainda menor do que se supunha e que desenvolveram uma estratégia reprodutiva mais similar a dos répteis basais do que a das aves. Se pterossauros eram altamente precociais ou necessitavam de cuidado parental ainda está aberto à discussão.

Palavras-chave: Pterosauria, Wukongopteridae, Biologia Reprodutiva, Jurássico, China.

\section{REFERENCES}

BENNETT SC. 2013. The phylogenetic position of the Pterosauria within the Archosauromorpha re-examined. Hist Biol 25: 545-563.

CASTANET J AND SMIRINA E. 1990. Introduction to the skeletochronological method in amphibians and reptiles. Zoologie 13 Serie 11: 191-196.

ChiAPPe LM, CODORNiÚ L, GRELLET-TinNER Gand Rivarola D. 2004. Argentinean unhatched pterosaur fossil. Nature 432: 571-572.

Chinsamy AT, Codorniú L AND Chiappe L. 2009. Palaeobiological Implications of the Bone Histology of Pterodaustro guinazui. Anat Rec 292: 1462-1477.

DEEMING DC. 2004. Reptilian incubation: environment, evolution and behaviour. Nottingham University Press.

DEEMING DC AND BIRCHARD GF. 2007. Allometry of egg and hatchling mass in birds and reptiles: roles of developmental maturity, eggshell structure and phylogeny. J Zool 271: 78-87.

Grellet-Tinner G, ThOMPSON MB, Fiorelli LE, ARgañaraZ E, CODORNIÚ L AND HECHENLEITNER EM. 2014. The first pterosaur 3-D egg: Implications for Pterodaustro guinazui nesting strategies, an Albian filter feeder pterosaur from central Argentina. Geoscience Frontiers 5: 759-765.
Grellet-Tinner G, Wroe S, Thompson MB AND JI Q. 2007. A note on pterosaur nesting behavior. Hist Biol 19(4): 273-277.

Hone DWE AND Benton MJ. 2008. Contrasting supertree and total-evidence methods: the origin of the pterosaurs. Zitteliana Reihe B 28: 35-60.

JI Q, JI SA, CHENG YN, YOU HL, LÜ JC, LIU YQ AND YUAN CX. 2004. Pterosaur egg with a leathery shell. Nature 432: 572 .

KELLNER AWA. 2004. The ankle structure of two pterodactyloid pterosaurs from the Santana Formation (Lower Cretaceous), Brazil. Bull Amer Museum Nat History 285: 25-35.

Kellner AWA. 2006. Pterossauros - os senhores do céu do Brasil. Rio de Janeiro: Vieira \& Lent.

Kellner AWA, Campos DA, Sayão JM, SARaiva AAF, Rodrigues T, OliVEIRA G, CRUZ LA, COSTA FR, Silva HP AND FERREIRA JS. 2013. The largest flying reptile from Gondwana: a new specimen of Tropeognathus cf. T. mesembrinus Wellnhofer, 1987 (Pterodactyloidea, Anhangueridae) and other large pterosaurs from the Romualdo Formation, Lower Cretaceous, Brazil. An Acad Bras Cienc 85: 113-135.

LEE AH AND WeRnING S. 2008. Sexual maturity in growing dinosaurs does not fit reptilian growth models. P Natl Acad Sci USA 105: 582-587.

LÜ JC, UNwIN DM, DEEMING DC, JIN XS, LIU YQ AND JI Q 2011a. An egg-adult association, gender, and reproduction in pterosaurs. Science 331: 321-324.

LÜ JC, UNWIN DM, JIN XS, LIU YQ AND Ji Q. 2010. Evidence for modular evolution in a long-tailed pterosaur with a pterodactyloid skull. Proc R Soc B 277: 383-389.

LÜ JC, XU L, Chang H AND Zhang X. 2011b. A new darwinopterid pterosaur form the Middle Jurassic of western Liaoning, northeastern China and its ecological implications. Acta Geol Sin 85: 507-514.

NORRIS DO AND LOPEZ KH. 2010. Hormones and Reproduction of Vertebrates - Vol 3: Reptiles. Waltham: Academic Press.

PAHL R, WINKLER DW, GRAVELAND J AND BATTERMAN BW. 1997. Songbirds do not create long-term stores of calcium in their legs prior to laying: results from high-resolution radiography. Proc R Soc B 264: 239-244.

Prondvai E, Stein K, Ösi A AND SANDER MP. 2012. Life History of Rhamphorhynchus Inferred from Bone Histology and the Diversity of Pterosaurian Growth Strategies. PLoS ONE 7: e31392.

REISS MJ. 1989. The Allometry of Growth and Reproduction. New York: Cambridge Univ Press.

RICQLÈS AJ, PADIAN K, HORNER JR AND FRANCILlONVIEILlOT H. 2000. Palaeohistology of the bones of pterosaurs (Reptilia: Archosauria): anatomy, ontogeny, and biomechanical implications. Zool J Linn Soc Lond 129: 349-385.

SATO T, CHENG YN, WU XC, ZELENITSKY DK AND HSIAO YF. 2005. A pair of shelled eggs inside a female dinosaur. Science 308: 375 . 
SAYÃO JM. 2003. Histovariability in bones of two pterodactyloid pterosaurs from the Santana Formation, Araripe Basin, Brazil: preliminary results. Geol Soc London, Spec Public 217: 335-342.

SCHWEITZER MH, ElSEy RM, DACKe CG AND HORNER JR. 2007. Do egg-laying crocodilian (Alligator mississippiensis) archosaurs form medullary bone? Bone 40: 1152-1158.

SCHWEITZER MH, WitTMEYER JL AND HORNER JR. 2005. Gender-specific reproductive tissue in ratites and Tyrannosaurus rex. Science 308: 1456-1460.

STEEL L. 2008. The palaeohistology of pterosaur bone: an overview. Zitteliana Reihe B 28: 109-125.

TINKLE DW, WILBUR HM AND TILLEY SG. 1970. Evolutionary strategies in lizard reproduction. Evolution 24: 55-74.

Wang X, Kellner AWA, Jiang S, Cheng X, Meng X AND RoDRIGUES T. 2010. New long-tailed pterosaurs (Wukongopteridae) from western Liaoning, China. An Acad Bras Cienc 82: 1045-1062.
Wang X, Kellner AWA, Jiang S And Meng X. 2009. An unusual long-tailed pterosaur with elongated neck from western Liaoning of China. An Acad Bras Cienc 81: 793-812.

WANG XL ET AL. 2014. Sexually dimorphic tridimensionally preserved pterosaurs and their eggs from China. Curr Biol 24(12): 1323-1330.

WANG X AND Zhou Z. 2004. Pterosaur embryo from the Early Cretaceous. Nature 429: 621.

WiTsCHI E. 1935. Seasonal sex characters in birds and their hormonal control. Wilson Bull 47: 177-188.

ZHeng XT, O'CONNOR J, HuChZERMEYer F, WANG XL, WANG Y, WANG M AND ZHOU ZH. 2013. Preservation of ovarian follicles reveals early evolution of avian reproductive behaviour. Nature 495: 507-511. 
